\title{
Waterlogging in the New Reclaimed Areas Northeast El Fayoum, Western Desert, Egypt, Reasons and Solutions*
}

\author{
El Sayed Ali El Abd'1, Maged Mostafa El Osta ${ }^{2}$ \\ ${ }^{1}$ Geology Department, Desert Research Centre, Cairo, Egypt \\ ${ }^{2}$ Geology Department, Faculty of Science, Damanhour University, Damanhour, Egypt \\ Email: drmagedelosta.edu.alex@hotmail.com
}

Received 1 October 2014; revised 28 October 2014; accepted 21 November 2014

Copyright (C) 2014 by authors and Scientific Research Publishing Inc.

This work is licensed under the Creative Commons Attribution International License (CC BY). http://creativecommons.org/licenses/by/4.0/

(c) (i) Open Access

\section{Abstract}

The waterlogging in the new reclaimed areas has become a major concern in the area Northeast El Fayoum, Western Desert, Egypt. It is not only endangering the structures and properties but also causing major environmental problem affecting the health of the area, habitats, and the biotic of the land community, as well as the deteriorating of Egypt's Pharaonic monuments (El Lahun and Hawarah pyramids). Both the daily seepage from excess irrigation water and the presence of impervious clay or limestone beds at shallow depths may represent the main contributor of groundwater rising in the shallow aquifer. This paper investigates the interplay of the hydrogeological characteristics, soil properties and recent land reclamation projects on the distribution of waterlogging and salinization within the study area. The field observations show that new reclaimed areas have been recently cultivated in distant areas from the old agricultural land. These new cultivations have developed widespread waterlogging, soil salinization and deterioration of Egypt's Pharaonic monuments as a result of rising groundwater related problems. In this paper, the data used come from database of drillings for eleven observation wells distributed inside the whole area to measure periodic water levels. The soil litho-units are mainly composed of coarse sand, sandy clay, silt and fractured limestone underlined by impervious clay or limestone, thus limiting the downward percolation of excess irrigation water and therefore develops waterlogging. The drainage networks and suitable irrigation methods have to be considered when planning for a new cultivation in dry land to better control waterlogging and salinization hazard. It is highly recommended in this research that newly small and deep cut drainage canals network should be constructed and connected to the master drainage canal to dewater the excess irrigation water

\footnotetext{
"Waterlogging in the new reclaimed areas Northeast El Fayoum, Western Desert, Egypt, reasons and solutions.
} 
and to prevent the waterlogging in the concerned area.

Keywords

Observation Wells, El Lahun and Hawarah Pyramids, Soils, Waterlogging, Drainage Canals Network

\section{Introduction}

In Egypt, the new reclaimed areas are being affected by soil salinity and waterlogging. In El Fayoum depression, Western Desert, Egypt, waterlogging problem is stated to be serious in the areas lying in the lower reaches of the concerned area [1] [2], reported how soil salinity and waterlogging problems have developed worldwide, and the speed with which they are advancing at present. Plants that are waterlogged are very susceptible to salinity, especially in their early growth stages [3]. Waterlogging and salinity problems pose a serious threat to the world's productive agricultural land. Disturbance of the natural balance by introducing irrigation causes a rising water table, where natural drainage sinks cannot cope with the increase in ground water recharge [4]. Recharge to deep aquifers is closely linked to the incidence of waterlogging [5] and to the development of land salinization. The major artificial causes of waterlogging in the command areas are seepage from water conveyance systems [6], breakages of regulatory structure, silting and weed growth in canals [7]. Lack of surface and sub-surface drainage, poor maintenance of drainage system, over irrigation and growing water intensive crops are some of major causes of poor realization of benefits from the irrigation systems [8] [9] indicated that due to the accumulation of organic matter, soil color is generally darker in poorly drained areas than well drained soils. Thus, a proper assessment of these waterlogged areas is a prerequisite for finding a solution to the problem. In general, for mapping of waterlogged areas, conventional technique such as ground survey observation wells are uses. There is growing concern about the decline in soil fertility, changes in water table depth, deterioration in the quality of irrigation water and rising salinity in the new reclaimed areas of Egypt.

El Fayoum depression is one of the most important agriculture lands of Egypt due to the good soil cover and the high crop productivity. The historical places as Hawwara and Lahun pyramids helped El Fayoum to be one of the wonderful tourism places in Egypt. It is exposed to several problems as waterlogging and soil salinization due to the human activities in the new reclaimed area located in the desert land in the periphery of the old cultivated land. These problems reduce the crop productivity in the old cultivated land. Tourism activities also leave its negative effect on the total income of El Fayoum governorate.

Hence, in the present study, a systematic attempt has been made for rapid, reliable assessment and delineation of the surface and sub-surface waterlogged areas in all the irrigation command areas of the Northeast El Fayoum, Western Desert, Egypt. As well as, a trial is made through this search to give an explanation for the geological and hydrological factors that leading to the evolution of these problems and accordingly suggesting suitable solutions to minimize their harmful effects.

\section{Study Area Description}

The study area, i.e. Northeast El Fayoum is located southwest of Cairo by about $100 \mathrm{Km}$ and northwest of BeniSuef by about $30 \mathrm{Km}$, and situated between $29^{\circ} 10^{\prime} \mathrm{N}$ and $29^{\circ} 20^{\prime} \mathrm{N}$ latitudes and $30^{\circ} 50^{\prime} \mathrm{E}$ and $31^{\circ} 00^{\prime} \mathrm{E}$ longitudes (Figure 1). It is now considered as the bread basket for the excess irrigation water from the new reclamation areas. The overall climate of this area is characterized by hot, long and dry summer and warm, short winter with scarce precipitation. Also, great temperature differences between summer and winter and between day and night characterizes this belt. The temperature ranges between $46.7^{\circ} \mathrm{C}$ and $35.1^{\circ} \mathrm{C}$ in summer months and from $20^{\circ} \mathrm{C}$ to $21.5^{\circ} \mathrm{C}$ during winter months. The average annual rainfall is around $10.3 \mathrm{~mm}$ which is relatively low. The total annual evaporation intensity reaches $2296 \mathrm{~mm} / \mathrm{year}$, and the annual mean of relative humidity is $51.6 \%$.

The geomorphology, stratigraphy and structure of El Fayoum area have attracted the attention of many researchers including [10]-[17], as well as the field observations of the present authors. Geomorphologically, the study area has been subdivided into the following units (Figure 2): 


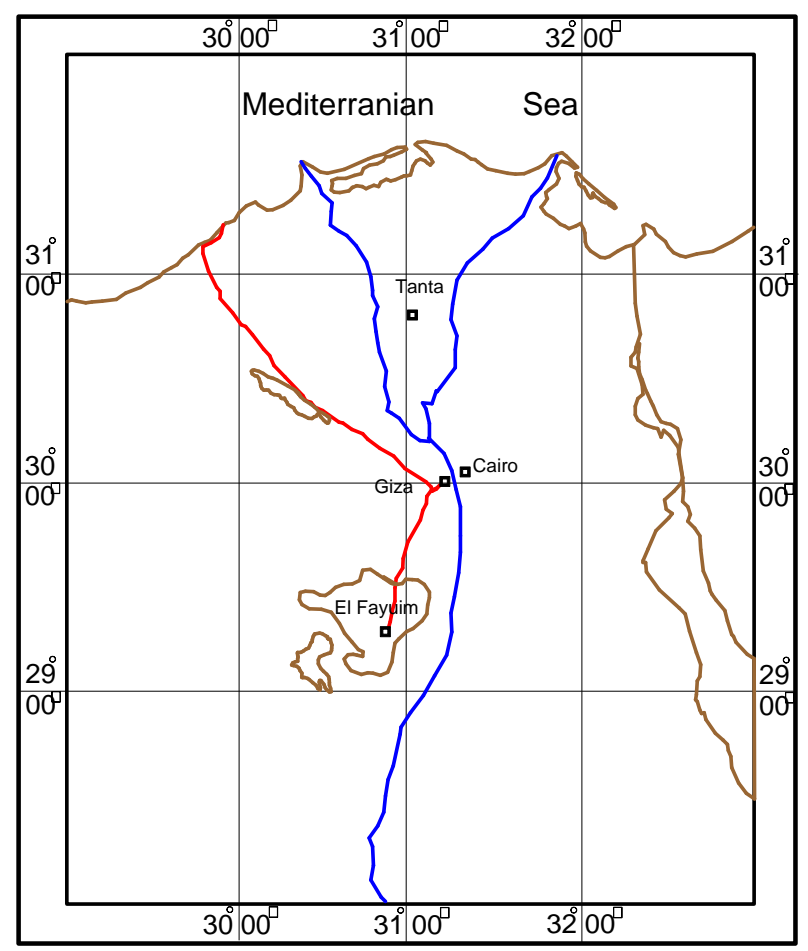

Figure 1. Location map of the study area.

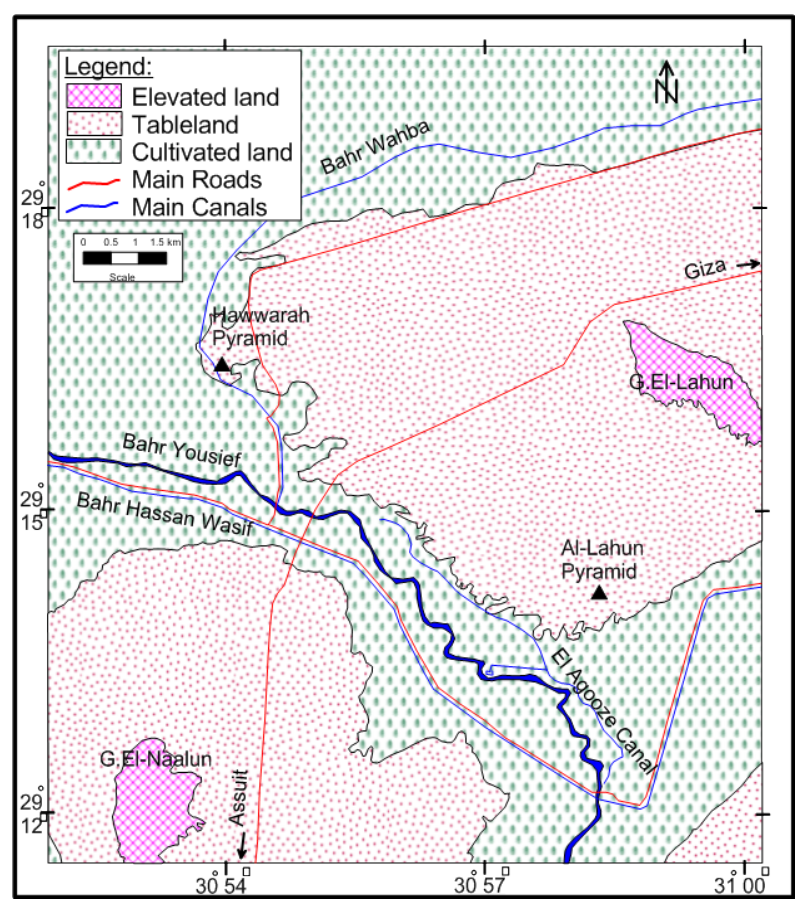

Figure 2. Geomorphologic map of the study area.

\subsection{Tableland}

Tableland Surrounds El Fayoum depression from the east and separating it from the Nile valley. Its elevation ranges between $+30 \mathrm{~m}$ and $+100 \mathrm{~m}$ above sea level and slopes with different degrees towards the Nile Valley and El Fayoum depression (Figure 3). It is mainly composed of Middle Eocene fractured limestone and dis- 


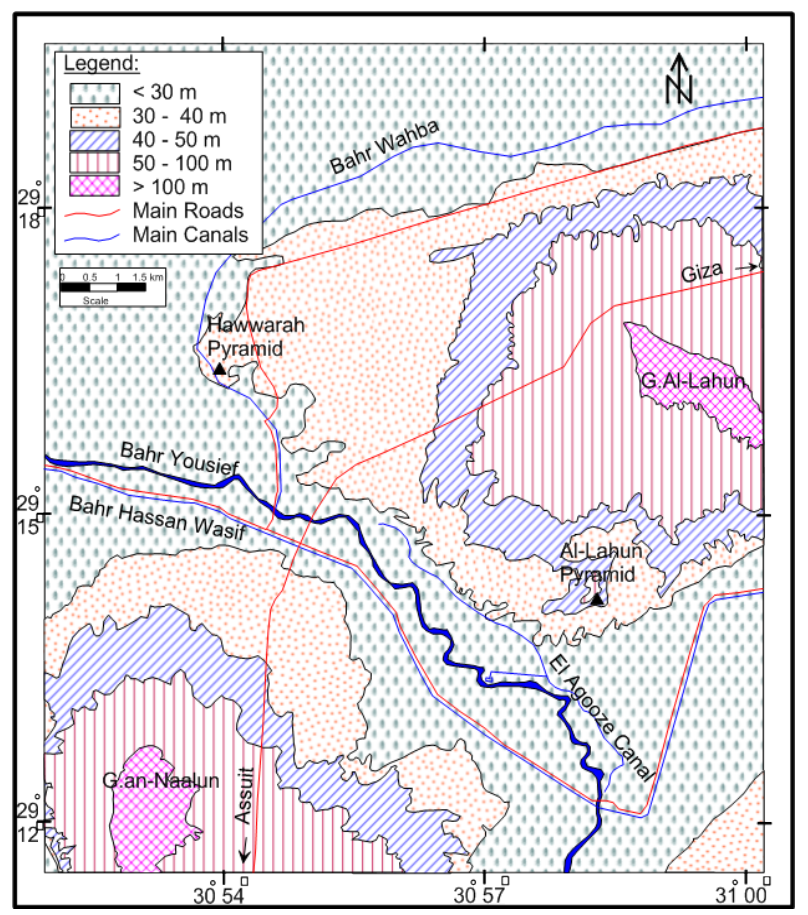

Figure 3. Orographic map of the study area.

sected by short drainage lines that are directed towards the Nile Valley and El Fayoum depression.

\subsection{Elevated Land}

Elevated land, is the high land overlooking the tableland and includes Gebel El Lahun (+144 m) and Gebel El Naalun ( +157 m). It is also as the tableland mainly composed of Middle Eocene fractured limestone and dissected by short drainage lines that are directed towards the Nile Valley and El Fayoum depression in the direction of the slope.

\subsection{Cultivated Land}

Cultivated Land is the eastern part of El Fayoum depression which characterized by good soil. Its surface is covered by lacustrine deposits with ground elevation less than $30 \mathrm{~m}$ above sea level (Figure 3). The outlet of El Fayoum depression to the Nile Valley is a part of this unit which represented by a narrow path Known as "Hawaret El Maktaa” between Gebel El Lahun and Gebel El Naalun. Through that path runs Bahr Youssef the main canal carrying the Nile water to the net of irrigation canals dissecting the El Fayoum depression floor. Reclamation projects are now under execution in the eastern peripheries of this land using Nile water in irrigation and create waterlogging problems in the neighboring old lands.

Geologically, El Fayoum and vicinities are occupied by sedimentary rocks belonging to Tertiary and Quaternary Eras (Figure 4). The surface exposure has a thickness of about $848 \mathrm{~m}$ [1]. Quaternary deposits are distinguished into, Holocene and Pleistocene deposits as follows:

The Holocene deposits are distinguished into; Aeolian deposits, young lacustrine deposits and young Nilotic deposits. Aeolian deposits are composed of loose quartz sand. Young lacustrine deposits are well defined in El Fayoum depression, associated with the lake development and composed of fine sand and clay with thin relics of gypsum and carbonate materials forming the agriculture soil. Young Nilotic deposits have a variable thickness ( $1 \mathrm{~m}$ to $12 \mathrm{~m}$ ) as a result of the seasonal Nile floods and composed of silt and fine sand dominated by quartz grains and heavy minerals.

The Pleistocene deposits are differentiated into Old lacustrine and Old Nilotic deposits. Old lacustrine deposits (45 m thick) are present within the depression area in the form of terraces at levels $+43 \mathrm{~m},+30 \mathrm{~m}$ and $+25 \mathrm{~m}$ indicating fresh water lake feeded by the Nile during the Pleistocene times. They consist mainly of clay, fine to 


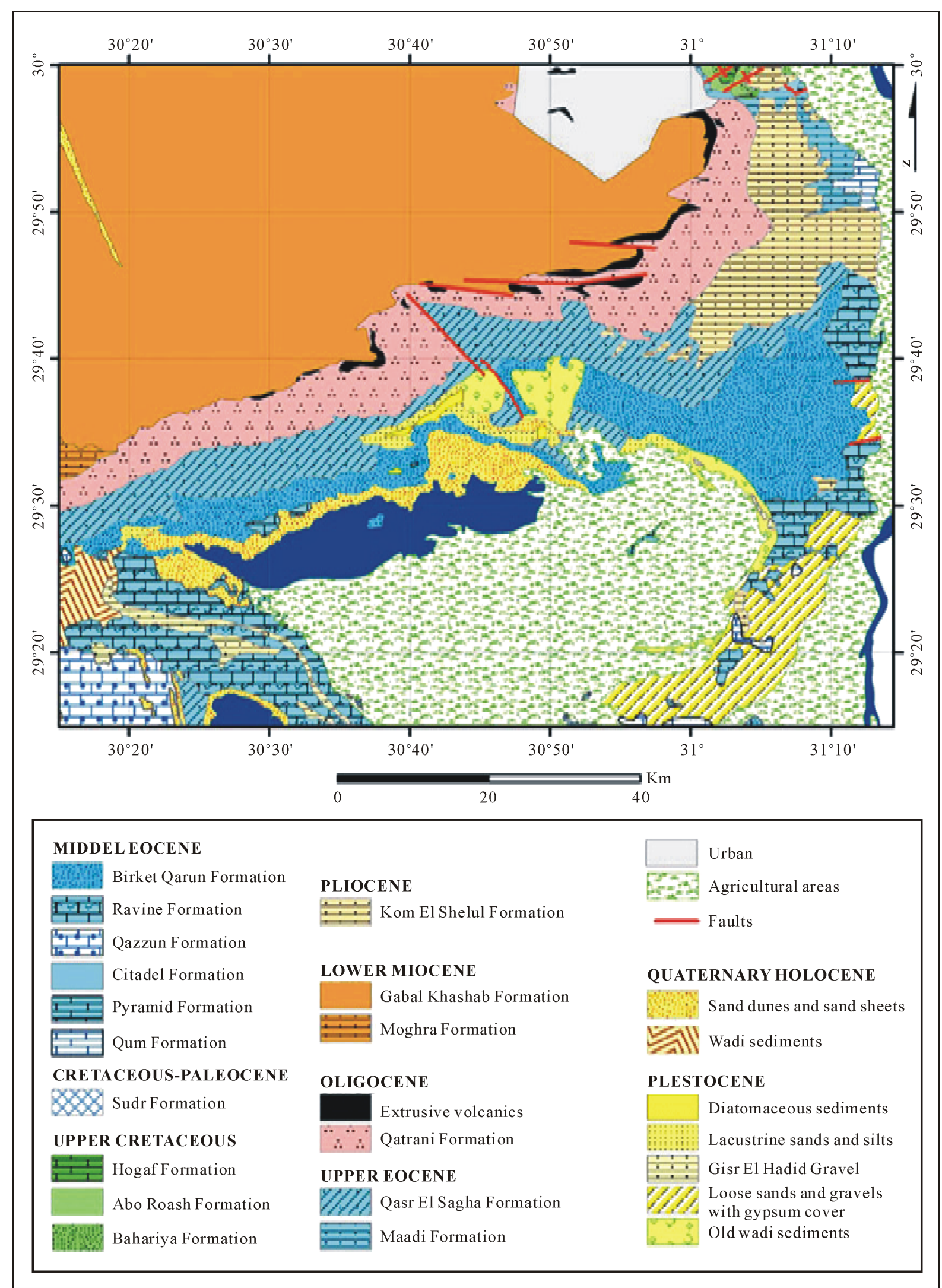

Figure 4. Geologic map of the study area [21]. 
medium coarse sand with considerable amounts of calcareous and gypsiferous materials. They show high content of mica, crystalline gypsum, iron, manganese oxides, sand debris, calcareous fragments and organic and fossil remains. Old Nilotic deposits (190 m thick) are recognized at the Nile-Fayoum divide where they are differentiated into terraces at levels $+89 \mathrm{~m},+112 \mathrm{~m},+134 \mathrm{~m}$ and $+167 \mathrm{~m}$. They are composed of sand and gravels forming a good groundwater aquifer.

Tertiary deposits are differentiated into Pliocene Miocene, Oligocene and Eocene rocks as follows:

The Pliocene deposits (90 m thick) are defined in the Nile-Fayoum divide forming of fossiliferous sandstone in some places overlain by Quaternary sand and gravels [11].

The Miocene rocks (20 m thick) are exposed at Gebel Qatrani to the north of El Fayoum depression overlying basalt exposures. They are composed of a series of alternating beds of sand and gravels with silicified wood remains.

The Oligocene rocks (275 m thick) are encountered underneath the Miocene rocks at Gebel Qatrani area and capped by basalt sheet. They are composed of sand and sandstone with shale and marl interbeds. These rocks are rich in silicified wood and land animals (crocodiles, tortoises and turtles).

The Eocene rocks (390 m thick) have a wide distribution in El Fayoum-Wadi El Rayan area [10]. They are distinguished into Upper and Middle Eocene rocks. Upper Eocene rocks are formed of a series of escarpments overlooking El Fayoum depression from the eastern side. The rock succession is composed mainly of sand (69\%), shale (19\%) and limestone (12\%) with high fossil content. These facies and faunal content indicate shallow marine environment. The Upper Eocene rocks were distinguished into two formations, the upper Qasr El Sagha Formation and the lower BirketQarun Formation, both are dominated at the northern extremities of the cultivated land fringing Qarun lake and the hill mass of GaretGehannam on the west side of El Fayoum depression. The thickness of both formations is about $180 \mathrm{~m}$ and $50 \mathrm{~m}$ respectively. On the other hand, Middle Eocene rocks constitute the oldest exposed rocks in El Fayoum area and its vicinities. They are represented mainly by limestone and marl with shale intercalations. They are discriminated into two formations, Raveine Formation and Wadi El Rayan Formation. The former appears below the alluvial deposits in the deep water channels and consists of gypseous shale, marl, limestone and sand. The other Formation is exposed at Wadi El Rayan where its outcrop composed of hard white limestone full of nummulitegizahensis, argillaceous sand and sandy shale.

Structurally, El-Faiyum depression is a structurally-controlled tectonic basin, marked by northeast-striking faults along its northern margin [18]. Qarun Lake is located in the northern part of El-Faiyum depression, at a right-step between two strands of the NE striking fault system. The E-W structures probably related to the relative motion between south Europe and north Egypt and closure of the Neotethys [19]. The continuation of these faults in the present area is only detected from magnetic and seismic studies.

The area of study is a new reclaimed area located in the eastern peripheries of the old cultivated land in El Fayoum depression. Nile water is the source of its irrigation by lifting. Bahr Wahba bonded the study area from north and northwest and Bahr yousief and El Agooze canal from south and southwest respectively. It dominated by two famous Egypt's Pharaonic monument pyramids; Hawarah and Al-Lahun (Figure 2). These pyramids are exposed to different deterioration processes (aging) caused by internal and external stresses due to the mineral composition of the building materials, climate factors and groundwater rising. All the existing elements of the pyramids are constructed from mud bricks which consist of quartz, kaolinite, calcite, montmorillonite, microcline and gypsum, as well as Eocene limestone which consists essentially of calcite and small amounts of halite [20]. There are two types of cements: clay cement consisting of quartz, orthoclase, calcite and illite, jointing the wall's structure of the pyramid and gypsum cement consisting of calcite and traces of gypsum and quartz jointing the stones. Wasp nests from the pyramid consist of fine grains of quartz and calcite joined by wasp saliva, while the salts are halite and gypsum. The actual state of the building materials of the pyramid is poor; the mud bricks are more friable and the limestone is weakened and highly porous due to exposure to deteriorating factors. The area of study is covered by fractured white Fossiliferous Limestone interbeded by impervious layer (clay and marl beds) and elevated than the surrounding old cultivated land.

Due to the traditional irrigation methods many dangerous lakes was formed and waterlogging appeared in the area causing serious damage in the new and old lands. Field observation shows that the land surface slopes towards these localities where, ground surface elevation reaches less than $+30 \mathrm{~m}$ (Figure 3). These areas receive both return flow of irrigation water and groundwater from the surrounding parts where depths to groundwater reaches less than one meter and groundwater levels coincide with the land surface under these localities (Figure 5). As well as, the moisture is drawn up into the stones of ancient buildings through capillary action and the 

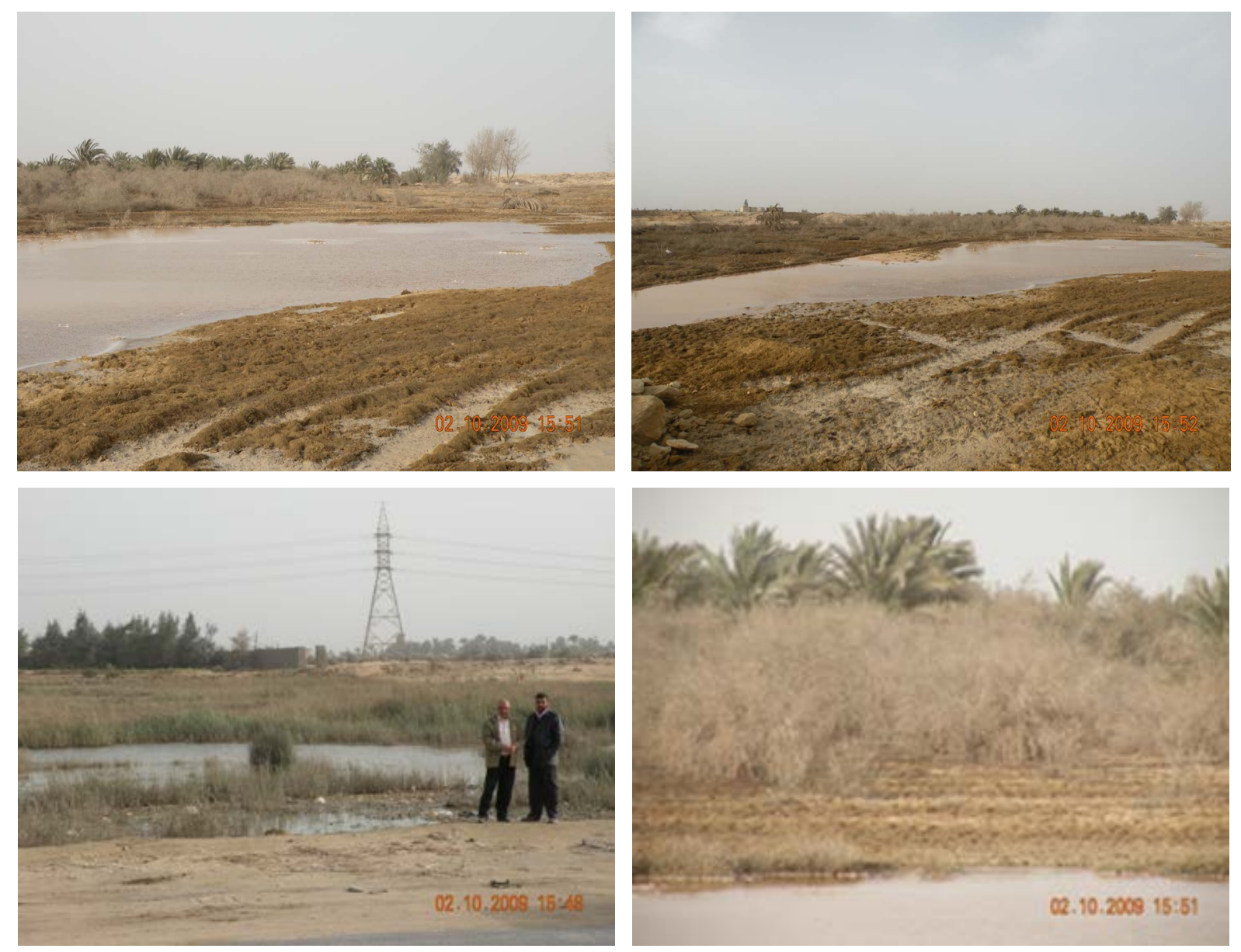

Figure 5. Field Photos show the developed waterlogging in the study area.

water table rises inside the Hawarah and Al-Lahun pyramids. Other factors such as the lack of advanced drainage system and the presence of impermeable shale and clay beds at shallow depths raised groundwater to and near the surface at some localities forming waterlogging and surface water ponding (Figure 5), this phenomenon destroyed the majority of the new reclaimed areas and the Egypt's greatest monuments could be vulnerable with collapse if action is not taken.

\section{Methods and Materials}

To study waterlogging problem in the concerned area, the following were preformed:

1) Survey of El Fayum toposheets at 1:50,000 scale was used for preparation of the base maps and for drilling observation wells.

2) Field work was conducted two times in the depression for this search from 2008 to 2010.

3) Using the interpreted Landsat ETM+ images and their photo-mosaics, the rock units have been checked and photo-graphed.

4) Eleven observation wells were constructed to measure periodic water levels (Figure 6).

5) Rock sample collection during construction of observation wells to study the type of subsurface rocks (Figure 7 and Table 1).

6) The aquifers properties and groundwater flow were examined using their hydraulic parameters and groundwater levels of the observation wells and 6 lakes during 2008 and 2010 to construct water level map and determine water flow direction.

7) To assess the waterlogged areas induced by rise in the ground water level near to the surface in the study area, ground water table data pertaining to pre- and post-monsoon seasons of the year 2008-2010 were collected 


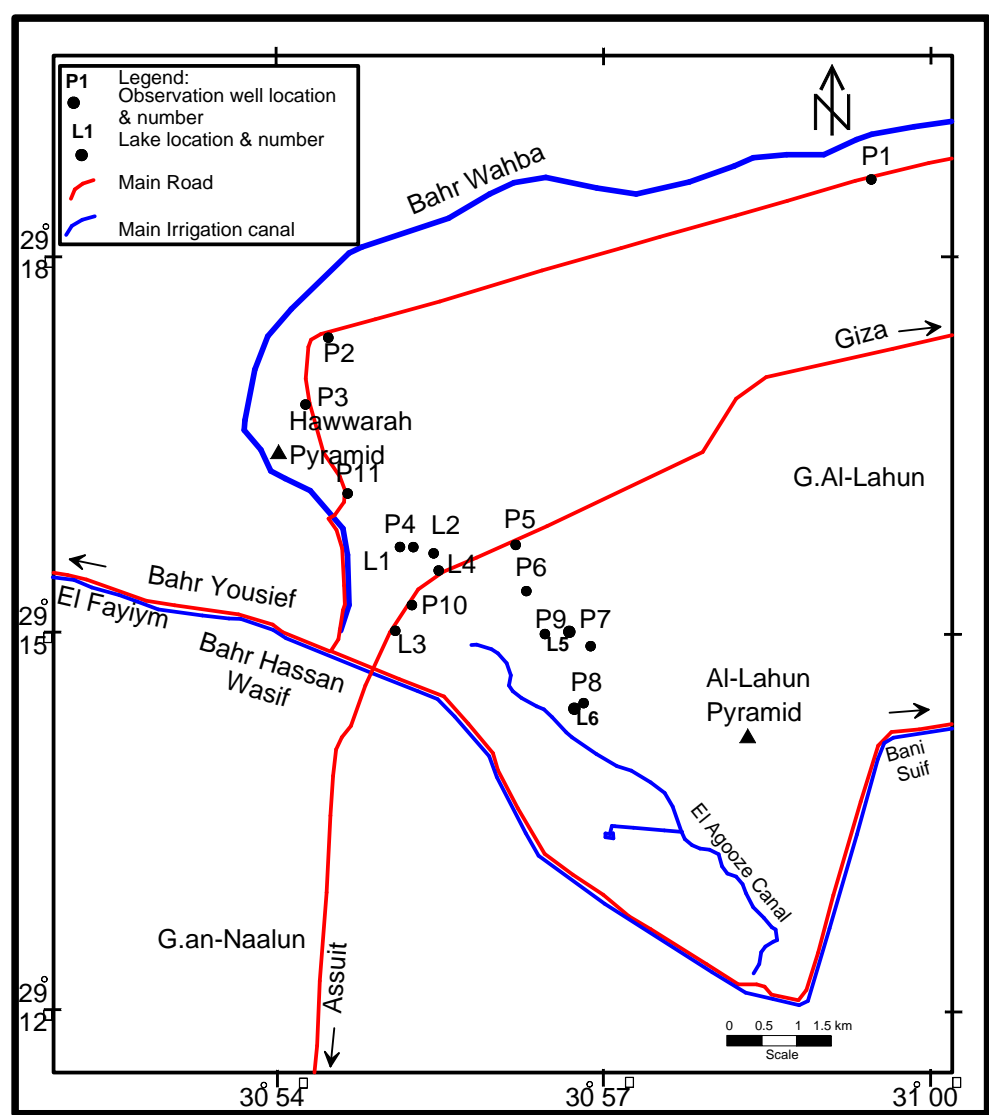

Figure 6. Location of the observation wells and lakes in the study area.
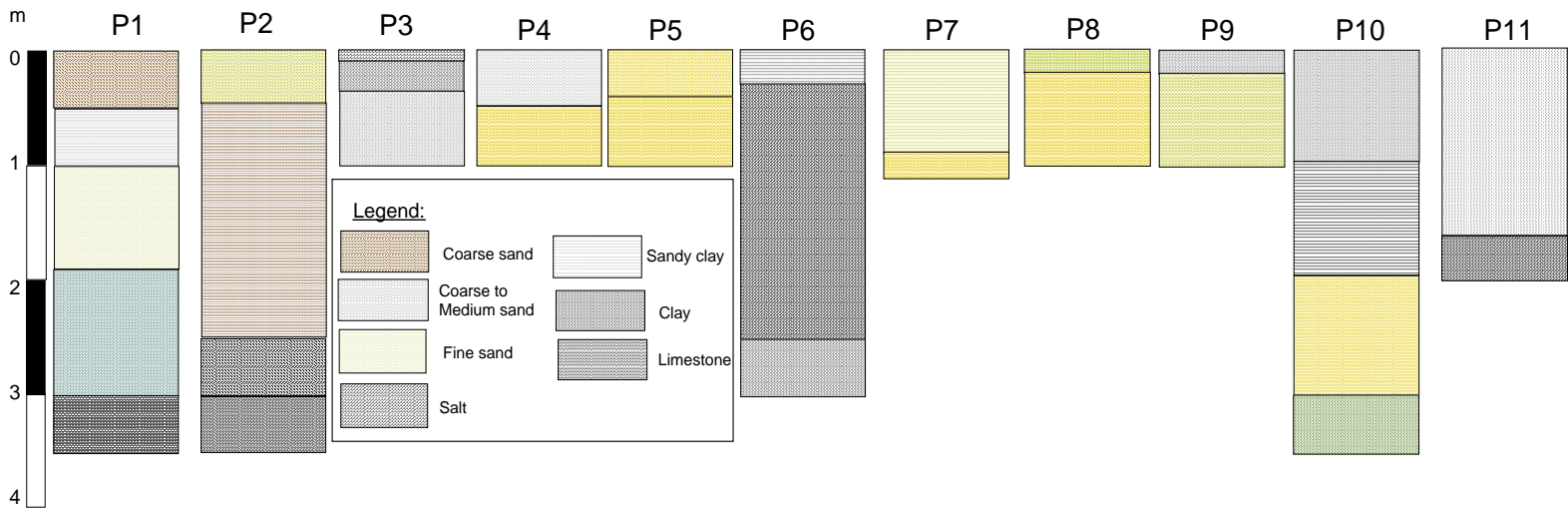

Figure 7. Lithologic logs of the observation wells in the study area.

for all the observation wells monitored by the author's which are spread all over the study area (Figure 9 and Figure 10).

8) Water samples were collected to study the hydrochemicall characteristics of the subsoil water.

\section{Results and Discussion}

Hydrogeologically, the various litho-units of the shallow aquifer in the study area can be grouped by coarse sand, sandy clay, silt and fractured limestone underlined by impervious clay (P1, P2, P3, P6, P9, P10 and P11) or limestone (P4, P5, P7 and P8) which prevent downward of irrigation water (Figure 7).

The observations on groundwater fluctuation (Figure 8) from January (2008) to January (2010) demonstrate a 
Table 1. Date of observation wells and lakes in the study area.

\begin{tabular}{|c|c|c|c|c|c|c|c|}
\hline $\begin{array}{c}\text { Observation } \\
\text { Well \& lake No. }\end{array}$ & $\begin{array}{c}\text { Total } \\
\text { depth (m) }\end{array}$ & Casing (m) & $\begin{array}{c}\text { Ground } \\
\text { elevation (m) }\end{array}$ & $\begin{array}{c}\text { Depth to water } \\
1 / 2008\end{array}$ & $\begin{array}{c}\text { Water level } \\
1 / 2008\end{array}$ & $\begin{array}{c}\text { Depth to water } \\
1 / 2010\end{array}$ & $\begin{array}{c}\text { Water level } \\
1 / 2010\end{array}$ \\
\hline P1 & 3.5 & 0.18 & 25.82 & 1.5 & 24.32 & 1.45 & 24.37 \\
\hline P2 & 3.4 & 0.31 & 29.224 & 0.97 & 28.254 & 0.95 & 28.274 \\
\hline P3 & 1 & 0.13 & 27.339 & 0.28 & 27.059 & 0.26 & 27.079 \\
\hline $\mathrm{P} 4$ & 0.8 & 0.25 & 25.359 & 0.4 & 24.959 & 0.38 & 24.979 \\
\hline P5 & 1 & 0.3 & 32.25 & 0.55 & 31.7 & 0.5 & 31.75 \\
\hline P6 & 3 & 0.39 & 34.861 & 0.83 & 34.031 & 0.80 & 34.061 \\
\hline P7 & 1.1 & 0.35 & 39.197 & 0.55 & 38.647 & 0.53 & 38.667 \\
\hline P8 & 1 & 0.15 & 34.015 & 0.25 & 33.765 & 0.21 & 33.805 \\
\hline P9 & 1 & 0.15 & 34.488 & 0.27 & 34.218 & 0.22 & 34.268 \\
\hline P10 & 3.5 & 0.16 & 25.375 & 0.45 & 24.925 & 0.37 & 25.005 \\
\hline P11 & 2 & 0.22 & 27.152 & 0.56 & 26.592 & 0.48 & 26.672 \\
\hline L1 & & & 24.734 & 0 & 24.734 & +0.05 & 24.784 \\
\hline L2 & & & 24.743 & 0 & 24.743 & +0.09 & 24.833 \\
\hline L3 & & & 25.573 & 0 & 25.573 & +0.06 & 25.633 \\
\hline L4 & & & 27.445 & 0 & 27.445 & +0.05 & 27.495 \\
\hline L5 & & & 35.609 & 0 & 35.609 & +0.08 & 35.689 \\
\hline L6 & & & 33.765 & 0 & 33.765 & +0.04 & 33.805 \\
\hline
\end{tabular}

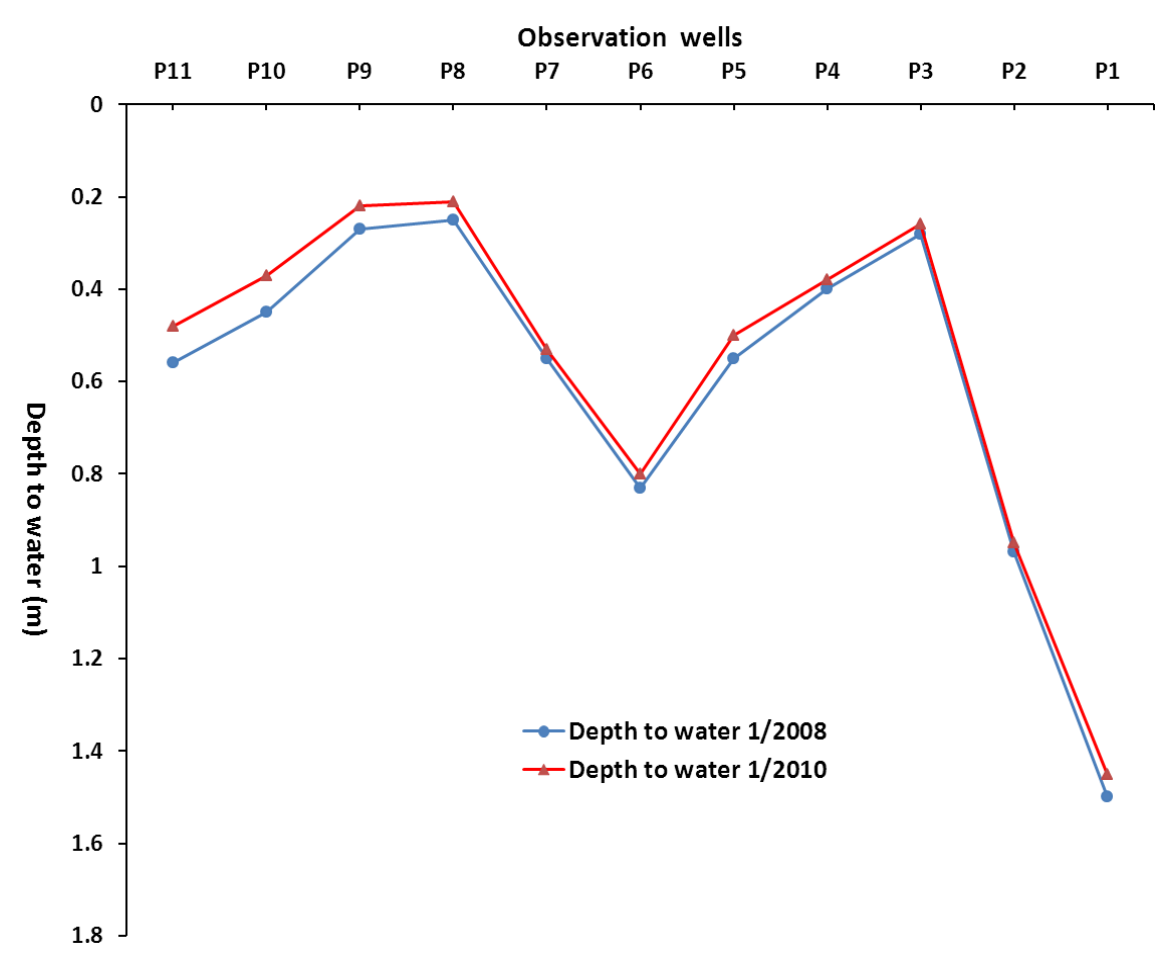

Figure 8. Depth to water fluctuation in the study area. 
relatively increase in water table by about $0.02 \mathrm{~m}$ (the lowest at P3) to $0.08 \mathrm{~m}$ (the highest at P11). The increase of groundwater levels occurred in practically all piezometers with different magnitudes with an annual average of $0.05 \mathrm{~m}$. On the other hand, the water tables of the command area for the year 2008-2010 are delineated and the integrated maps are shown in Figure 9 and Figure 10. Comparing water levels of 1/2008 (Figure 9) and water level of 1/2010 (Figure 10), cleared that all the observation wells and the lakes have increase in the water level from $0.09 \mathrm{~m}$ (L2) to $0.02 \mathrm{~m}$ (p3). As well as, the subsoil water moves from the high level land located in the middle of the concerned area towards the low land (old cultivated land) located in the periphery of the new reclaimed land and the two ancient pyramids (Hawarah and Al-Lahun) causing serious waterlogging and damage of the old cultivated land. Groundwater threatens more than the great monument's stability. If water wicks up into the statue, it will leach salts from the limestone and deposit them on the surface of the stones. Eventually, the salts will accelerate the flaking erosion and the fall of clay plaster and cement that has long afflicted the Hawarah and Al-Lahun pyramids as well as the salt crystallization in the entrance (Figure 11). The deteriorating mechanism of salt solution depends on two sources of water: humidity from condensation and groundwater from capillary rise In order to protect the antiquities from further accelerated deterioration, lowering of groundwater to safe levels was needed.

The hydrogeochemical characteristics of the sub-soil water in the study area are discussed through the chemical analysis of eleven sub-soil water samples (beside irrigation canals water samples) collected during January 2008 (Table 2). The chemical analyses deal with the determination of major cations $\left(\mathrm{Na}^{+}, \mathrm{K}^{+}, \mathrm{Ca}^{2+}\right.$ and $\mathrm{Mg}^{2+}$ ) and anions $\left(\mathrm{CO}_{3}^{-}, \mathrm{HCO}_{3}^{-}, \mathrm{SO}_{4}^{2-}\right.$ and $\left.\mathrm{Cl}^{-}\right)$. According to Chebotarev classification for salinity [22], the subsoil water of the study area can be classified from brackish water to high saline water. The salt content of the water samples ranges from 32,816 mg/l (P8) to $4224.4 \mathrm{mg} / \mathrm{l}$ (P11). Furthermore, the salinity increases generally towards the northwest of the study area (Figure 12). Hyper-saline water is restricted to high land area reflecting the effect of gypsiferous shale beside the infiltration of high saline excess irrigation water. Saline water is restricted to low land in the periphery of the old cultivated land (P1, P2 and P11) reflecting the effect of fresh

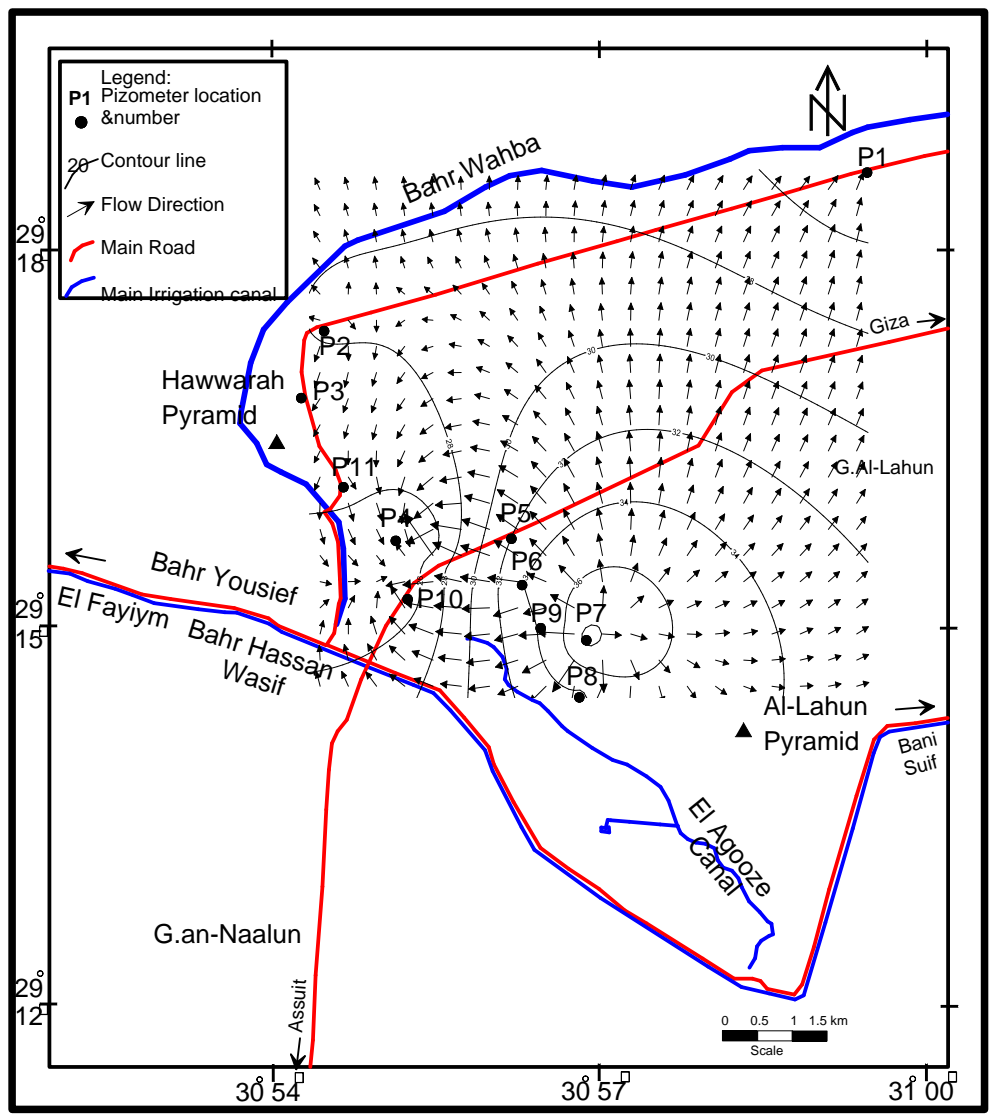

Figure 9. Water level contour map in the study area (2008). 


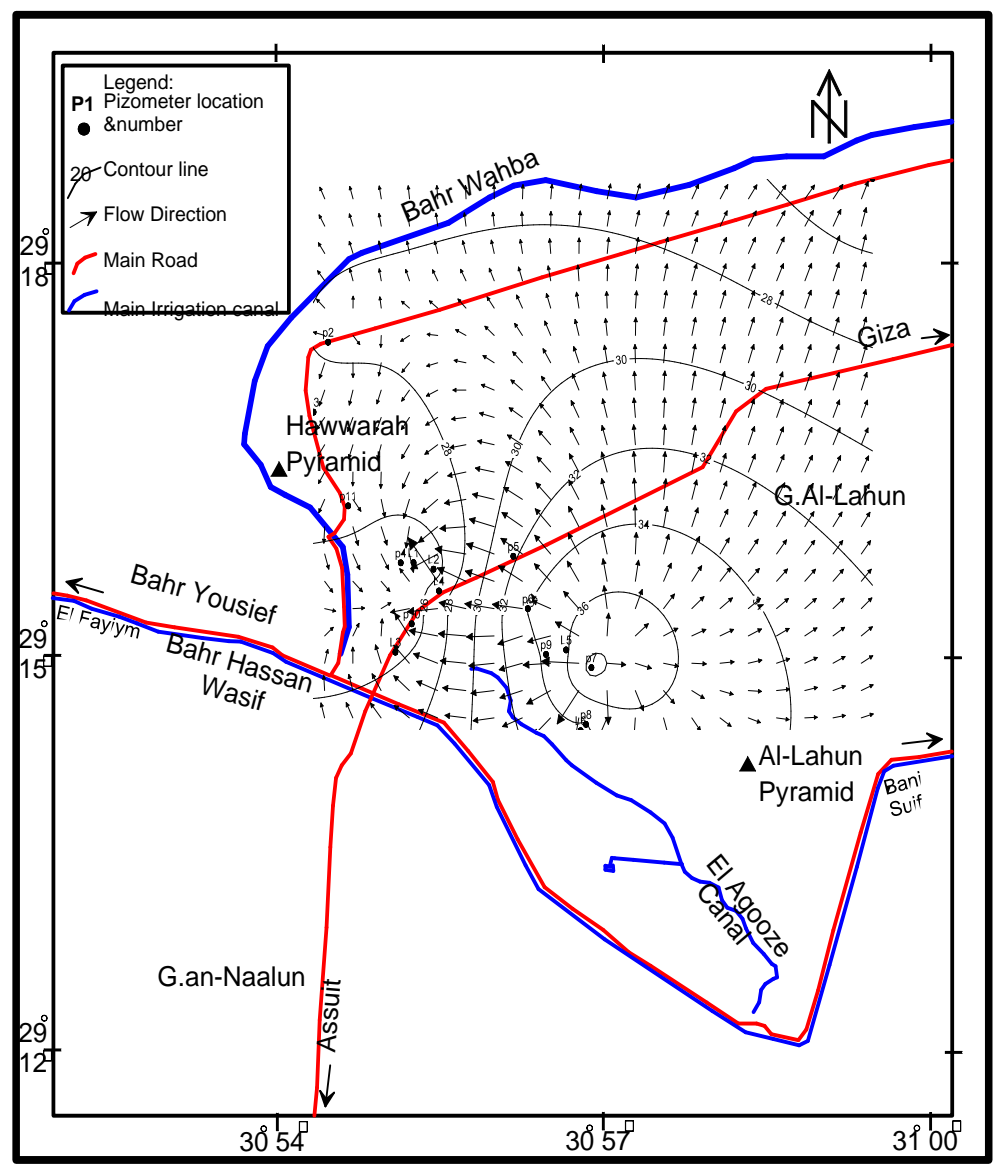

Figure 10. Water level contour map in the study area (2010).
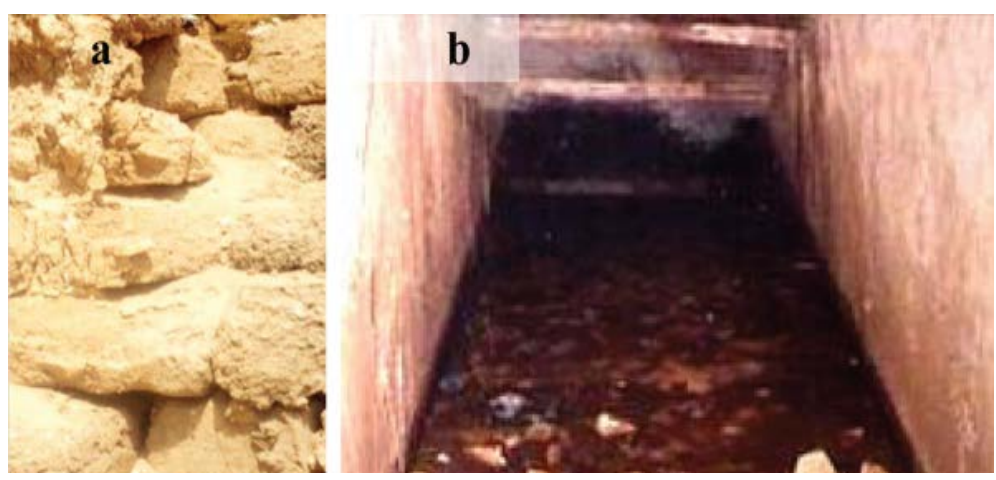

Figure 11. Examples of destruction types in Hawarah and Al-Lahun pyramids: (a) Fall of clay plaster and cement; (b) Salt crystallization in the entrance.

water of the irrigation canal and the sub-soil composed of coarse to fine sand intercalated with sandy clay and clayey sand. Regarding major cations and anions, sodium is predominant cation followed by calcium or magnesium and magnesium or calcium $\left(\mathrm{Na}^{+}>\mathrm{Ca}^{2+}>\mathrm{Mg}^{2+}\right.$ or $\left.\mathrm{Na}^{+}>\mathrm{Mg}^{2+}>\mathrm{Ca}^{2+}\right)$, (Table 2). High sodium concentration is possibly due to leaching processes of clay and shale. Concerning major anions, sulfide is the mostly predominant anions followed by chloride or bicarbonates and bicarbonates or chloride $\left(\mathrm{SO}_{4}^{2-}>\mathrm{Cl}^{-}>\mathrm{HCO}_{3}^{-}\right.$or $\mathrm{SO}_{4}^{2-}>\mathrm{HCO}_{3}^{-}>\mathrm{Cl}^{-}$). High sulfide concentration is possibly due to leaching processes of clay and shale present, the effect of sulfide fertilizer and the infiltration of high saline excess irrigation water. 
Table 2. Hydrogeochemical data of the observation wells and irrigation water in the study area.

\begin{tabular}{|c|c|c|c|c|c|c|c|c|c|c|c|c|c|}
\hline $\begin{array}{l}\text { Well } \\
\text { No. }\end{array}$ & $\begin{array}{l}\text { E.C } \mu \mathrm{M} \\
\text { hos/cm }\end{array}$ & $\begin{array}{l}\text { TDS } \\
(\mathrm{mg} / \mathrm{l})\end{array}$ & Units & $\mathrm{Ca}^{2+}$ & $\mathrm{Mg}^{2+}$ & $\mathrm{Na}^{+}$ & $\mathrm{K}^{+}$ & Sum. Cat. & $\mathrm{CO}_{3}^{-}$ & $\mathrm{HCO}_{3}^{-}$ & $\mathrm{SO}_{4}^{2-}$ & $\mathrm{Cl}^{-}$ & Sum. An. \\
\hline \multirow{3}{*}{ P1 } & \multirow{3}{*}{70,600} & \multirow{3}{*}{48472.7} & $\mathrm{mg} / \mathrm{l}$ & 300 & 97.28 & 16,000 & 150 & \multirow{3}{*}{722.49} & 0 & 100.8 & 23,000 & 8875 & \multirow{3}{*}{730.79} \\
\hline & & & meq/l & 14.97 & 8.00 & 695.68 & 3.84 & & 0.00 & 1.65 & 478.86 & 250.28 & \\
\hline & & & $\mathrm{e} \%$ & 2.07 & 1.11 & 96.29 & 0.53 & & 0.00 & 0.23 & 65.53 & 34.25 & \\
\hline \multirow{3}{*}{ P2 } & \multirow{3}{*}{70,100} & \multirow{3}{*}{45291.2} & $\mathrm{mg} / \mathrm{l}$ & 220 & 188.5 & 15,000 & 150 & \multirow{3}{*}{682.52} & 0 & 378 & 22,000 & 7543.8 & \multirow{3}{*}{676.97} \\
\hline & & & meq/l & 10.98 & 15.50 & 652.20 & 3.84 & & 0.00 & 6.20 & 458.04 & 212.73 & \\
\hline & & & $\mathrm{e} \%$ & 1.61 & 2.27 & 95.56 & 0.56 & & 0.00 & 0.92 & 67.66 & 31.42 & \\
\hline \multirow{3}{*}{ P3 } & \multirow{3}{*}{138,600} & \multirow{3}{*}{84332.3} & $\mathrm{mg} / \mathrm{l}$ & 320 & 486.4 & 30,000 & 300 & \multirow{3}{*}{1368.05} & 0 & 226.8 & 18,500 & 34,613 & \multirow{3}{*}{1364.96} \\
\hline & & & meq/l & 15.97 & 40.00 & 1304.40 & 7.68 & & 0.00 & 3.72 & 385.17 & 976.07 & \\
\hline & & & $\mathrm{e} \%$ & 1.17 & 2.92 & 95.35 & 0.56 & & 0.00 & 0.27 & 28.22 & 71.51 & \\
\hline \multirow{3}{*}{$\mathrm{P} 4$} & \multirow{3}{*}{179,100} & \multirow{3}{*}{113,750} & $\mathrm{mg} / \mathrm{l}$ & 750 & 361.7 & 39,500 & 300 & \multirow{3}{*}{1792.31} & 0 & 126 & 35,500 & 37,275 & \multirow{3}{*}{1792.33} \\
\hline & & & meq/l & 37.43 & 29.75 & 1717.46 & 7.68 & & 0.00 & 2.07 & 739.11 & 1051.16 & \\
\hline & & & $\mathrm{e} \%$ & 2.09 & 1.66 & 95.82 & 0.43 & & 0.00 & 0.12 & 41.24 & 58.65 & \\
\hline \multirow{3}{*}{ P5 } & \multirow{3}{*}{94,700} & \multirow{3}{*}{61764.3} & $\mathrm{mg} / \mathrm{l}$ & 440 & 273.6 & 20,500 & 150 & \multirow{3}{*}{939.63} & 0 & 176.4 & 27,000 & 13,313 & \\
\hline & & & meq/l & 21.96 & 22.50 & 891.34 & 3.84 & & 0.00 & 2.89 & 562.14 & 375.41 & 940.44 \\
\hline & & & $\mathrm{e} \%$ & 2.34 & 2.39 & 94.86 & 0.41 & & 0.00 & 0.31 & 59.77 & 39.92 & \\
\hline & & & $\mathrm{mg} / \mathrm{l}$ & 280 & 152 & 6320 & 77 & & 6.0001 & 189 & 10,000 & 3328.1 & \\
\hline P6 & 30,000 & 20257.6 & meq/l & 13.97 & 12.50 & 274.79 & 1.97 & 303.24 & 0.20 & 3.10 & 208.20 & 93.85 & 305.35 \\
\hline & & & $\mathrm{e} \%$ & 4.61 & 4.12 & 90.62 & 0.65 & & 0.07 & 1.01 & 68.18 & 30.74 & \\
\hline & & & $\mathrm{mg} / \mathrm{l}$ & 220 & 103.4 & 2200 & 74 & & 0 & 138.6 & 4580 & 652.31 & \\
\hline P7 & 11,300 & 7898.97 & meq/l & 10.98 & 8.50 & 95.66 & 1.89 & 117.03 & 0.00 & 2.27 & 95.36 & 18.40 & 116.02 \\
\hline & & & $\mathrm{e} \%$ & 9.38 & 7.26 & 81.74 & 1.62 & & 0.00 & 1.96 & 82.19 & 15.85 & \\
\hline & & & $\mathrm{mg} / \mathrm{l}$ & 550 & 136.8 & 10,500 & 150 & & 0 & 113.4 & 14,500 & 6922.5 & \\
\hline P8 & 50,100 & 32,816 & meq/l & 27.45 & 11.25 & 456.54 & 3.84 & 499.07 & 0.00 & 1.86 & 301.89 & 195.21 & 498.96 \\
\hline & & & $\mathrm{e} \%$ & 5.50 & 2.25 & 91.48 & 0.77 & & 0.00 & 0.37 & 60.50 & 39.12 & \\
\hline & & & $\mathrm{mg} / \mathrm{l}$ & 320 & 115.5 & 4000 & 63 & & 0 & 113.4 & 6550 & 2218.8 & \\
\hline P9 & 20,400 & 13,324 & meq/l & 15.97 & 9.50 & 173.92 & 1.61 & 201.00 & 0.00 & 1.86 & 136.37 & 62.57 & 200.80 \\
\hline & & & $\mathrm{e} \%$ & 7.94 & 4.73 & 86.53 & 0.80 & & 0.00 & 0.93 & 67.91 & 31.16 & \\
\hline & & & $\mathrm{mg} / \mathrm{l}$ & 100 & 206.7 & 2500 & 18 & & 0 & 970.2 & 4800 & 532.5 & \\
\hline P10 & 13,100 & 8642.31 & meq/l & 4.99 & 17.00 & 108.70 & 0.46 & 131.15 & 0.00 & 15.90 & 99.94 & 15.02 & 130.85 \\
\hline & & & $\mathrm{e} \%$ & 3.80 & 12.96 & 82.88 & 0.35 & & 0.00 & 12.15 & 76.37 & 11.48 & \\
\hline & & & $\mathrm{mg} / \mathrm{l}$ & 100 & 115.5 & 1150 & 44.5 & & 0 & 630 & 2100 & 399.38 & \\
\hline P11 & 6370 & 4224.39 & meq/l & 4.99 & 9.50 & 50.00 & 1.14 & 65.63 & 0.00 & 10.33 & 43.72 & 11.26 & 65.31 \\
\hline & & & e\% & 7.60 & 14.47 & 76.19 & 1.74 & & 0.00 & 15.81 & 66.95 & 17.24 & \\
\hline & & & $\mathrm{mg} / \mathrm{l}$ & 60 & 6.08 & 157.5 & 7 & & 0 & 277.2 & 220.5 & 44.375 & \\
\hline $\begin{array}{l}\text { Irrig. } \\
\text { Water }\end{array}$ & 1080 & 634.055 & meq/l & 2.99 & 0.50 & 6.85 & 0.18 & 10.52 & 0.00 & 4.54 & 4.59 & 1.25 & 10.39 \\
\hline & & & $\mathrm{e} \%$ & 28.46 & 4.75 & 65.09 & 1.70 & & 0.00 & 43.75 & 44.20 & 12.05 & \\
\hline
\end{tabular}




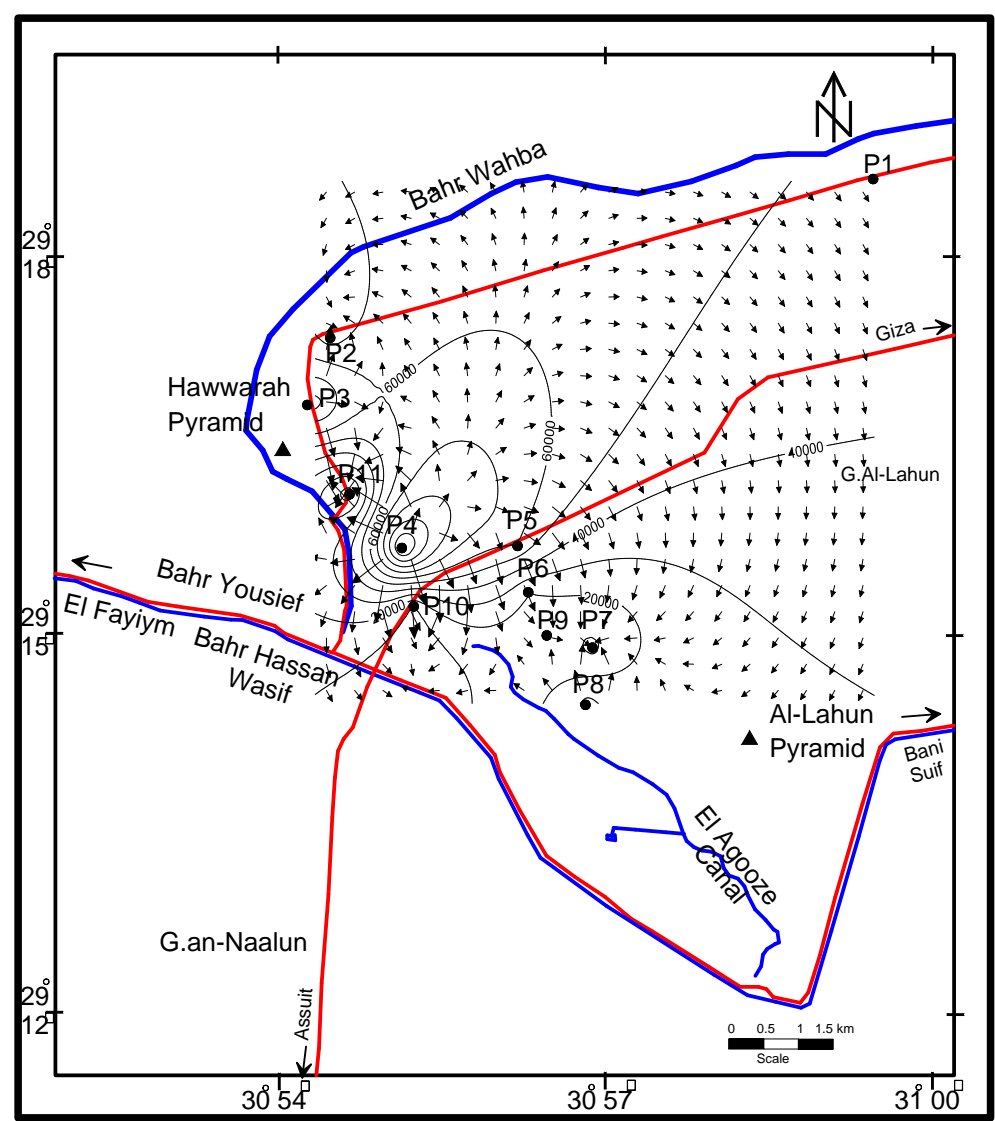

Figure 12. Salinity distribution map of sub-soil water in the study area (2008).

\section{Reasons Resulted in the Waterlogging Problem}

The major causes of waterlogging in the study area include excessive irrigation water supplies, seepage losses from canals, impeded sub-surface drainage and lack of proper land development. The movement of seepage water downstream has resulted in the accumulation of surface ponds, particularly in the cultivated low areas [23]. Further, litho-units of the shallow aquifer which cover major portion of the northeast El Fayoum command area are also responsible to waterlogging. These units are very deep, imperfectly to poorly drained and underlined by impervious clay or limestone which prevent downward of irrigation water. Overall, waterlogging problems in most of irrigation command areas can also be attributed to the absence drainage canal networks in the study area.

\section{Solution of the Waterlogging Problem}

In order to protect the antiquities from further accelerated deterioration, lowering of groundwater to safe levels was needed as follows:

- Main drainage canal should be constructed in the periphery of the old cultivated land and around the pyramids to dewatering the excess irrigation water (Figure 13).

- Secondary small and deep cut drainage canals network may be constructed in the all the study area and connected to the main drainage canal to dewater the excess irrigation water (Figure 13).

- Convert irrigation system in the new reclaimed lands from traditional (flood irrigation) to other advanced irrigation methods as shower and drip.

- Continuous monitoring of water levels to show the early detection of decline in subsoil water after constructing the drainage canals network, and hence taking the necessary corrective actions to prevent any negative impacts on groundwater level. 


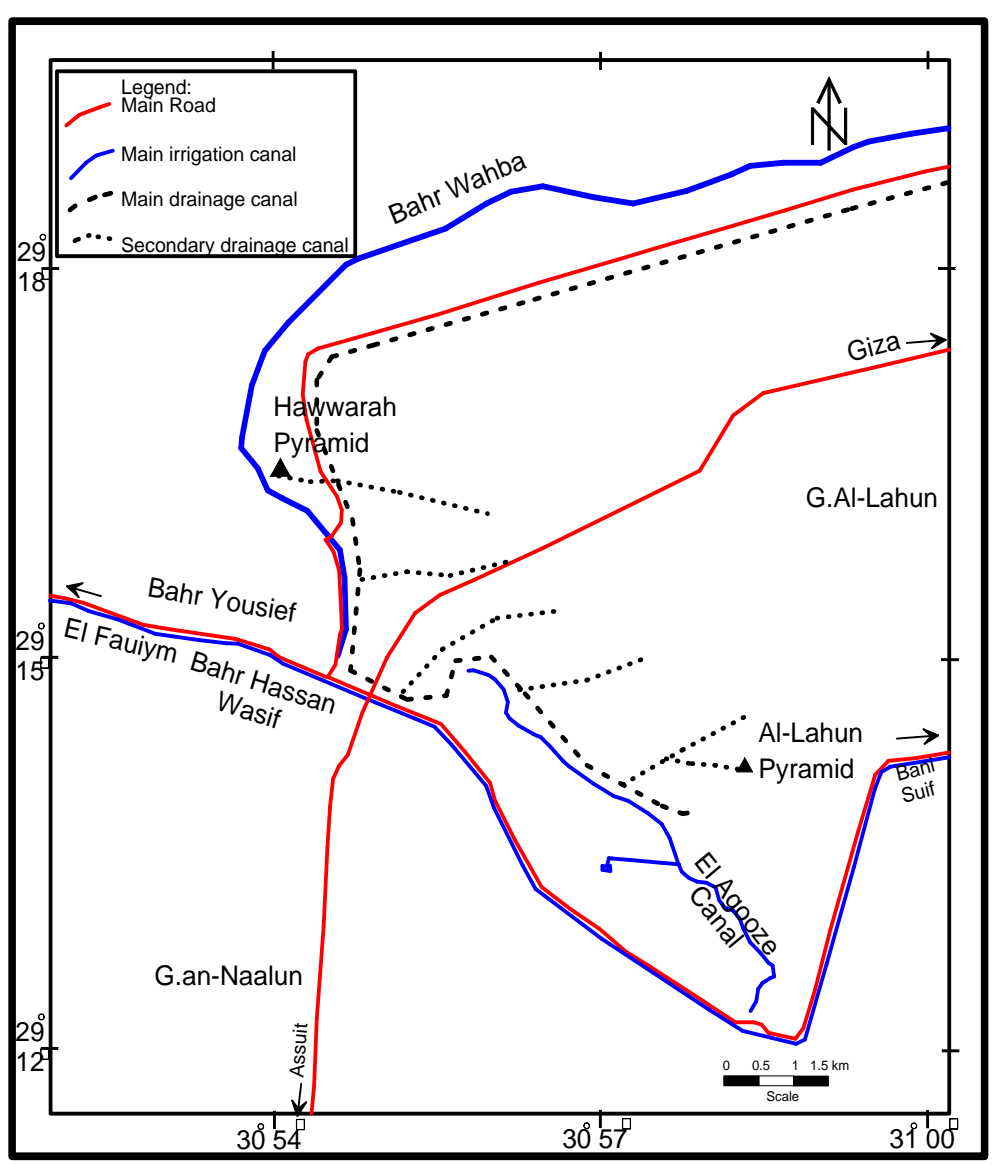

Figure 13. The proposed drainage canals network in the study area.

\section{Conclusion}

Reliable assessment of waterlogged areas forms a critical element in the irrigation command area development program as well as in the famous Egypt's Pharaonic monument pyramids. In the present study, eleven observation wells were constructed to measure periodic water levels in order to evaluate the impact of canal irrigation. The subsoil water moves from the high level land located in the middle of the concerned area towards the low land (old cultivated land) located in the periphery of the new reclaimed land and the two ancient pyramids (Hawarah and Al-Lahun) causing serious waterlogging and damage of the old cultivated land. The major causes of waterlogging include excessive irrigation water supplies, seepage losses from canals, impeded sub-surface drainage and lack of proper land development. Further, litho-units of the shallow aquifer which cover major portion of the northeast El Fayoum command area are also responsible to waterlogging. These units are very deep, imperfectly to poorly drained and underlined by impervious clay or limestone which prevent downward of irrigation water as well as the absence drainage canal networks in the study area. In order to protect the antiquities from further accelerated deterioration, lowering of groundwater to safe levels was needed by suggesting the construction of drainage canals network in the periphery of the old cultivated land and around the pyramids to dewatering the excess irrigation water in the study area.

\section{References}

[1] El-Sheikh, A.E. (2004) Water Budget Analysis of the Quaternary Deposits for the Assessment of the Water Logging Problem in El Fayoum Depression. Ph.D. Thesis, Faculty of Science, Al-Azhar University, Egypt, 356 p.

[2] Hoffman, G.J. and Durnford, D.S. (2000) Drainage Design for Salinity Control. In: Skaggs, R.W. and van Schilfgaarde, J., Eds., Agricultural Drainage. Agronomy No.: 38. American Society of Agronomy, Madison, 579-614. Khouri, N. (1998) Potential of Drydrainage for Controlling Soil Salinity. Canadian Journal of Civil Engineering, 25, 
195-205.

[3] Barrett-Lennard, E. (2002) Restoration of Saline Land through Revegetation. Agric. Water Manage, 53, 13-26. http://dx.doi.org/10.1016/S0378-3774(01)00166-4

[4] Gowing, J.W. and Wyseure, G.C.L. (1992) Dry-Drainage a Sustainable and Cost-Effective Solution to Waterlogging and Salinization. Proceedings of 5th International Drainage Workshop, Vol. 3, ICID-CIID, Lahore Pakistan, 6.266.34 .

[5] Moore, G.A. and McFarlane, D.J. (1998) Waterlogging. In: Moore, G., Ed., Soil Guide—A Handbook for Understanding and Managing Agricultural Soils, Agriculture Western Australia, South Perth,

[6] Brahmabhatt, V.S., Dalwadi, G.B., Chhabra, S.B., Ray, S.S. and Dadhwal, V.K. (2000) Land Use/Land Cover Change Mapping in Mahi Canal Command Area, Gujarat, Using Multitemporal Satellite Data. Journal of the Indian Society of Remote Sensing, 28, 221-232. http://dx.doi.org/10.1007/BF02990813

[7] Dutta, D., Sharma, J.R., Bothale, R.V. and Bothale, V. (2004) Assessment of Waterlogging and Salt Affected Soils in the Command Areas of All Major and Medium Irrigation Project in India. Technical Document, Regional Remote Sensing Service Centre, Jodhpur, 1-74.

[8] Choubey, V.K. (1997) Detection and Delineation of Waterlogging by Remote Sensing Techniques. Journal of the Indian Society of Remote Sensing, 25, 123-135. http://dx.doi.org/10.1007/BF03025910

[9] Wildman, W.E. (1982) Detection and Management of Soil Irrigation Management in Mendoza. In: Menenti, M. (Ed.), Argentina. Remote Sensing in Evaluation and Management of irrigation. Institute Nacional de Cienciay Tenicas Hidricas Mendoza, Argentina, 37-58.

[10] Beadnell, H.J.L. (1905) The Topography and Geology of the Fayum Province of Egypt. Survey Department of Egypt, Cairo, 101.

[11] Said, R. (1962) The Geology of Egypt. Elsevier, Amsterdam.

[12] Said, R. (1981) The Geological Evolution of the River Nile. Springer, Berlin.

[13] Tamer, A. M. (1968) Subsurface Geology of the Fayoum Region. M.Sc. Thesis, Alexandria University, Alexandria.

[14] Vondra, C.F. (1974) Upper Eocene Transitional and Near-Shore Marine Qasr El Sagha Formation, Fayum Depression, Egypt. Annals of the Geological Survey of Egypt, 4, 74-94.

[15] Abdel Hafez, N.A. (1991) Geological and Geochemical Studies on Pleistocene Old Lacustrine in El Fayoum Depressions, Western Desert Egypt. Minia Sc. Bull., 4, 145-162.

[16] Swedan, A.H. (1992) Stratigraphy of the Eocene Sediments in El Fayoum Area. Annals of the Geological Survey of Egypt, 18, 157-166.

[17] Kusky, T.M., Yahia, M.A. and Ramadan, T. (2001) Notes on the Structural and Neotectonic Evolution of El-Faiyum Depression, Egypt: Relationships to Earthquake Hazards. Egyptian Journal of Remote Sensing and Space Sciences, 2, $1-12$.

[18] Timothy, M.K., Talaat, M.R., Mahmoud, M.H. and Safwat G. (2011) Structural and Tectonic Evolution of El-Faiyum Depression, North Western Desert, Egypt Based on Analysis of Landsat ETM+, and SRTM Data. Journal of Earth Science, 22, 75-100. http://dx.doi.org/10.1007/s12583-011-0159-8

[19] Kusky, T.M. and Ramadan, T. (2002) Structural Controls on Neo-Proterozoic Mineralization in the SE Desert, Egypt: An Integrated Field, Landsat TM, and SIR-C/X SAR Approach. Journal of African Earth Sciences, 35, 107-121. http://dx.doi.org/10.1016/S0899-5362(02)00029-5

[20] Pinińska, J. and Hemdan, E. (2008) Geomechanical Study of Building Materials of the Hawara Pyramid (Fayoum, Egypt). Geologija, 50, 126-130.

[21] Hermina, M., Klitzsch, E. and List, F. (1987) Stratigraphic Lexicon and Explanatory Notes to the Geologic Map of Egypt 1:500,000. Continental Oil Company (CONOCO), Cairo.

[22] Chebotarev I. (1955) Metamorphism of Natural Waters in the Crust of Weathering. Geochimica et Cosmochimica Acta, 8, 137-170.

[23] El Bastawesy, M., Ali, R., Faid, A. and El Osta, M.M. (2013) Assessment of Waterlogging in Agricultural Megaprojects in the Closed Drainage Basins of the Western Desert of Egypt. Hydrology and Earth System Sciences, 17, 14931501. 
Scientific Research Publishing (SCIRP) is one of the largest Open Access journal publishers. It is currently publishing more than 200 open access, online, peer-reviewed journals covering a wide range of academic disciplines. SCIRP serves the worldwide academic communities and contributes to the progress and application of science with its publication.

Other selected journals from SCIRP are listed as below. Submit your manuscript to us via either submit@scirp.org or Online Submission Portal.
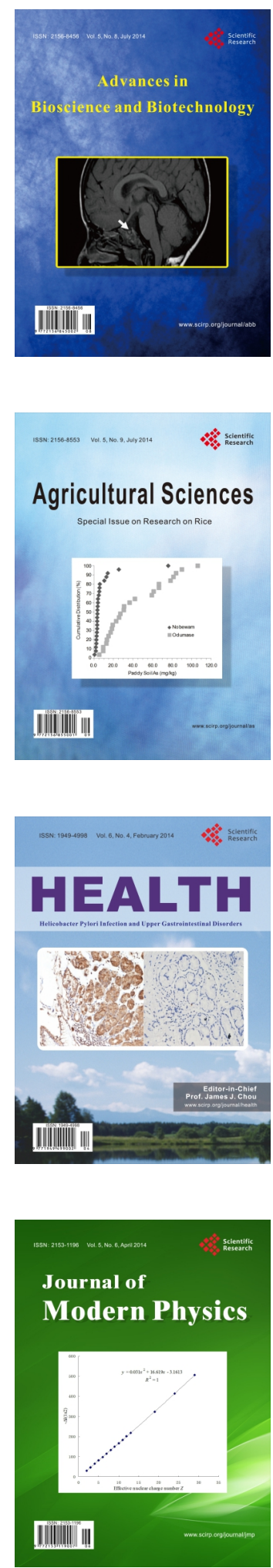
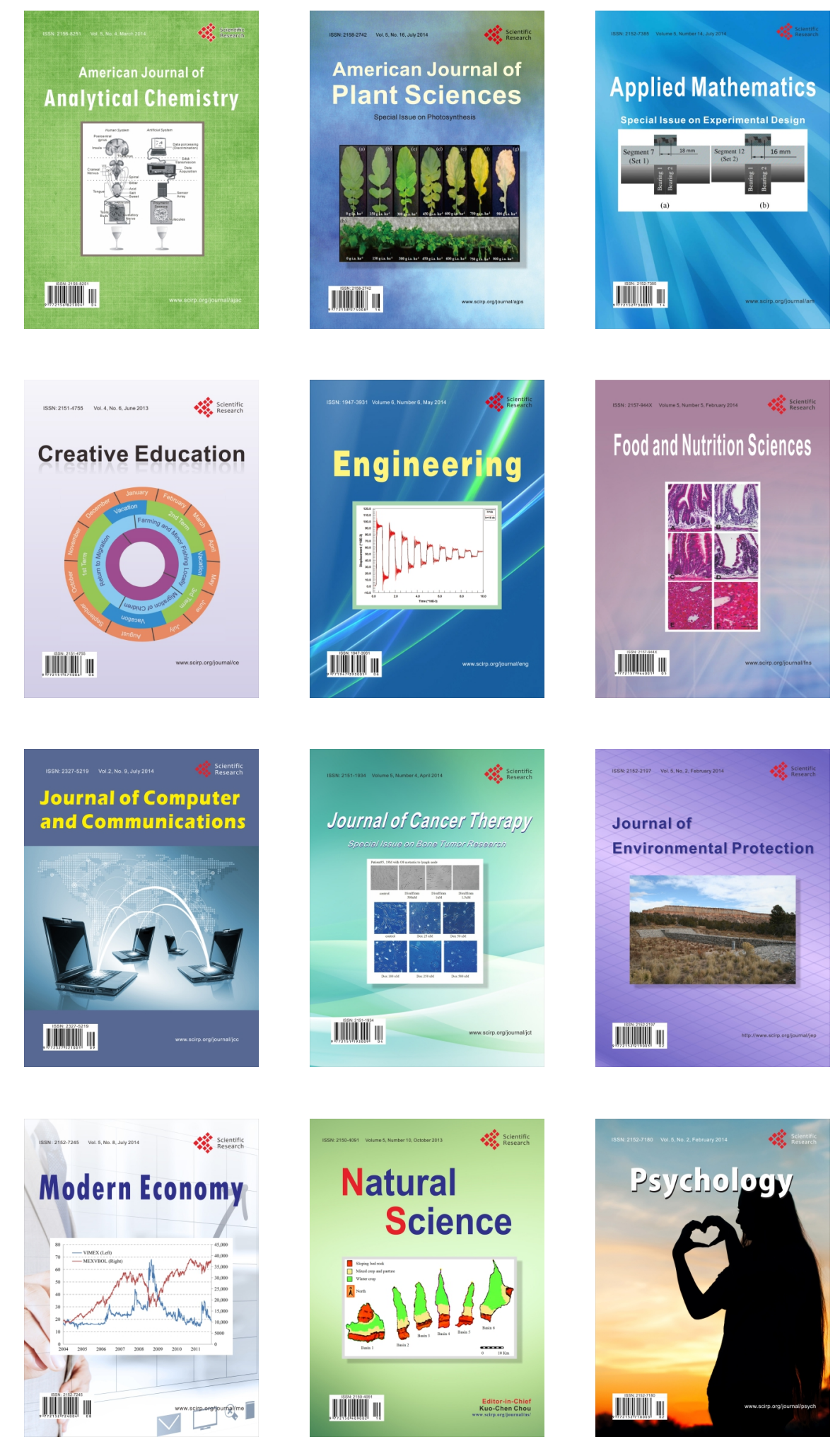